\title{
Recyclable cobalt-molybdenum bimetallic carbide modified separator boosts the polysulfide adsorption- catalysis of lithium sulfur battery
}

\author{
Ze Zhang ${ }^{1}$, Jia-Nan Wang ${ }^{2,3}$, A-Hu Shao ${ }^{1}$, Dong-Gen Xiong ${ }^{1}$, Jian-Wei Liu ${ }^{3}$, Cheng-Yen Lao ${ }^{2}$, \\ Kai Xi ${ }^{2,4^{*}}$, Shi-Yao Lu ${ }^{5}$, Qiu Jiang ${ }^{4}$, Ji Yu ${ }^{1}$, Huang-Long Li ${ }^{6^{*}}$, Zhen-Yu Yang ${ }^{1^{*}}$ and R. Vasant Kumar ${ }^{2}$
}

\begin{abstract}
The polysulfide shuttling and sluggish redox kinetics, due to the notorious adsorption-catalysis underperformance, are the ultimate obstacles of the practical application of lithium-sulfur (Li-S) batteries. Conventional carbon-based and transition metal compound-based material solutions generally suffer from poor catalysis and adsorption, respectively, despite the performance gain in terms of the other. Herein, we have enhanced polysulfide adsorptioncatalytic capability and protected the $\mathrm{Li}$ anode using a complementary bimetallic carbide electrocatalyst, $\mathrm{Co}_{3} \mathrm{Mo}_{3} \mathrm{C}$, modified commercial separator. With this demonstration, the potentials of bimetal compounds, which have been well recognized in other environmental catalysis, are also extended to Li-S batteries. Coupled with this modified separator, a simple cathode (S/Super $\mathbf{P}$ composite) can deliver high sulfur utilization, high rate performance, and excellent cycle stability with a low capacity decay rate of $\sim 0.034 \%$ per cycle at $1 \mathrm{C}$ up to 1000 cycles. Even at a high S-loading of $8.0 \mathrm{mg} \mathrm{cm}^{-2}$ with electrolyte/sulfur ratio $=6 \mathrm{~mL} \mathrm{~g}^{-1}$, the cathode still exhibits high areal capacity of $\sim 6.8 \mathrm{~mA} \mathrm{~h} \mathrm{~cm}{ }^{-2}$. The experimental analysis and the first-principles calculations proved that the bimetallic carbide $\mathrm{Co}_{3} \mathrm{Mo}_{3} \mathrm{C}$ provides more binding sites for adsorbing polysulfides and catalyzing the multiphase conversion of sulfur/polysulfide/sulfide than monometallic carbide $\mathrm{Mo}_{2} \mathrm{C}$. Moreover, the modified separator can be reutilized with comparable electrochemical performance. We also showed other bimetallic carbides with similar catalytic effects on Li-S batteries and this material family has great promise in
\end{abstract}

different energy electrocatalytic systems.

Keywords: lithium-sulfur batteries, bimetallic carbides, electrocatalysts, polysulfide adsorption-catalysis, modified separators

\section{INTRODUCTION}

The continuous success in pursuing long-range electric vehicles (EVs) impels the exploration of high-energy battery chemistry beyond the traditional ion-insertion type $[1,2]$. Rechargeable lithium-sulfur (Li-S) batteries have emerged as a promising alternative to the state-ofthe-art Li-ion batteries with a much higher theoretical specific energy at $2600 \mathrm{~W} \mathrm{~h} \mathrm{~kg}^{-1}$ and much lower cathode price $\left(0.05 \$ \mathrm{~kg}^{-1}\right.$ for sulfur) [3-6]. The Li-S electrochemistry, however, is plagued by intrinsically high electrical resistivity of elemental $\mathrm{S}\left(2 \times 10^{15} \Omega \mathrm{m}\right.$ at $\left.20^{\circ} \mathrm{C}\right)$ and high soluble and diffusive lithium polysulfides [7-9]. Above all, the necessary incorporation of Li metallic anode means further challenges in unstable surface and severe safety concerns due to the dendrite formation and the unwanted reactions between Li metal and polysulfides during shuttling process [10-12].

Separators, as the indispensable part of the battery design, directly contact and interact with both the cathode and the anode, thereby determining the battery performance [13]. In particular, separators play a vital role in Li-S batteries due to the complicated phase transformation of elemental S. In a common Li-S configuration, the

${ }^{1}$ School of Chemistry, Nanchang University, Nanchang 330031, China

${ }^{2}$ Department of Materials Science and Metalliclurgy, University of Cambridge, Cambridge CB3 OFS, UK

${ }^{3}$ Department of Environmental Science and Engineering, Department of Applied Chemistry, School of Science, Key Laboratory for Nonequilibrium Synthesis and Modulation of Condensed Matter (Ministry of Education), State Key Laboratory for Electrical Insulation and Power Equipment, Xi'an Jiaotong Univrsity, Xi'an 710049, China

${ }^{4}$ Department of Engineering, University of Cambridge, CB3 0FA Cambridge, UK

${ }^{5}$ Department of Chemistry, City University of Hong Kong, Tat Chee Avenue, Kowloon, Hong Kong, China

${ }^{6}$ Department of Precision Instrument, Tsinghua University, Beijing 10084, China

* Corresponding authors (emails: kx210@cam.ac.uk (Xi K); li_huanglong@mail.tsinghua.edu.cn (Li HL); zyyang@ncu.edu.cn (Yang ZY)) 
soluble polysulfides diffuse freely through the commercially available separators, leading to active material loss and Li anode corrosion [14,15], as illustrated in Fig. 1a-c. To this end, functionalizing the cathode-facing side of the separators with various materials has been recognized as a feasible and effective strategy to localize the polysulfide shuttling only on the cathode side, and further enhance the Li-S battery performance [16-22]. Once a modified separator is employed in the Li-S configuration, the significant enhancement in the electrochemical performance including higher S utilization, prolonged cycle life and better rate capability can be observed even with a simple S/Super P cathode.

Initially, the separators were modified with various kinds of carbon materials [23-27] as the basis for functional separators to limit the polysulfide migration. Notably, given the fact that the absorption ability of polysulfides mainly depends on the pore structures of carbon substrates [28]. Hierarchical pore distribution, especially the mixed micropore/low-range mesopore $[29,30]$, is well accepted as the favorable carbon substrate. Whilst porous carbon-modified separator could enable fast ion transfer and good polysulfide shuttling control via the physical restriction (Fig. 1b, d), not all confined polysulfides can be reutilized because of the severe irreversible deposition of insoluble sulfides. Furthermore, in terms of polysulfide anchoring and conversion, polar metallic compounds with abundant active sites can more effectively chemically interact with polysulfide species than carbon materials [31-35]. Therefore, they are combined with carbonaceous materials as the chemical-type separators to retard the polysulfide shuttling. The issue is that most of metallic oxides and sulfides are semiconductors or even insulators, which might impede the $\mathrm{Li}^{+}$ion transfer between the $\mathrm{S}$ cathode and $\mathrm{Li}$ anode [20]. More importantly, the confined polysulfides are not ex-

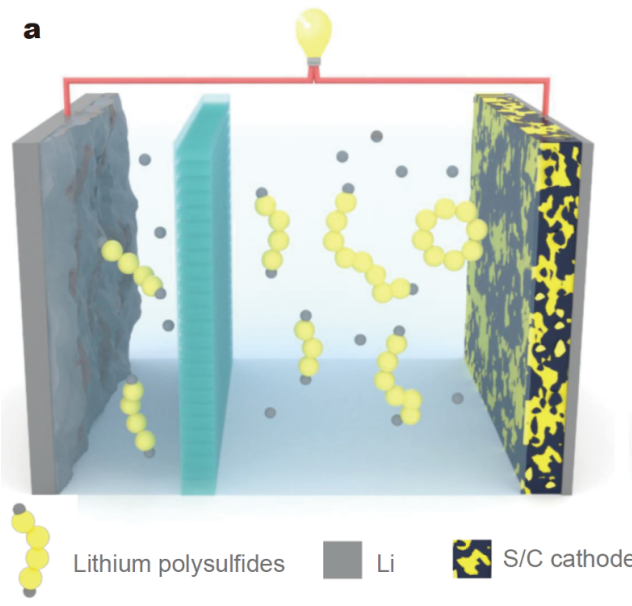

b
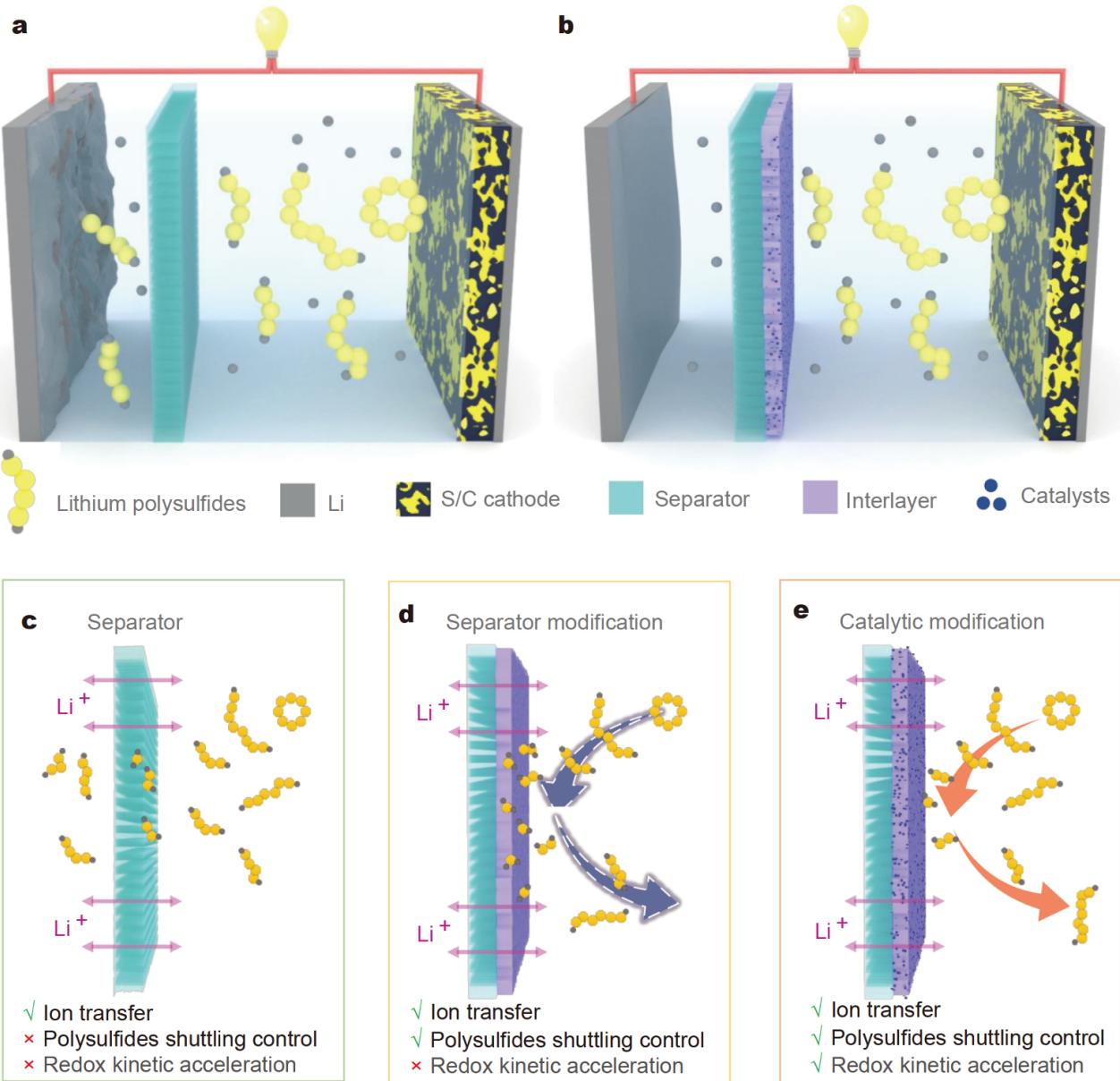

Figure 1 Schematic illustration of the working principle of Li-S battery. (a) Routine and (b) functional Li-S configurations with PP separator. Polysulfide redox of different Li-S configurations: (c) bare separator, and functional separators modified with (d) carbon-based materials, and (e) postulated desirable materials. 
pected to be favorably reduced or oxidized during subsequent cycles, which were impeded on the nonconductive substrate surface due to the sluggish interface redox kinetics [36,37].

Recently, as a new mechanistic understanding of the catalytic effect of polysulfide conversion emerged, researchers realized the great potential of applying various catalytic host materials [38-42] to boost the electrochemical kinetics of polysulfide redox reaction. Therefore, we expect that a desirable modified separator (Fig. 1e) should be able to catalyze the polysulfide redox kinetics to reutilize the confined polysulfides, along with its chemisorption toward polysulfides and fast ion conductivity $[43,44]$. The ideal option is an integrated material of a hybrid of metallic compound catalysts and carbon substrate since the reaction kinetics are intrinsically limited by the heterogeneity of the materials [20]. In addition, cations are considered as the real active sites in metallic compound electrocatalysts, and multimetallic compounds are likely to exhibit extraordinary electrocatalytic activity [45]. Recently, bimetallic nanomaterials have been well recognized as the efficient electrocatalysts in oxygen reduction/evolution reaction [46-48], while their extensive application and the mechanism in Li-S batteries are still unrevealed. In spite of some reports on some bimetallic oxides [31,49] and hydroxides [37], being effective in Li-S batteries as additives or S-host, there is little comprehensive understanding on the catalytic behavior of bimetallic compounds, let alone their superiority over monometallic compounds. Especially whilst incorporating with porous carbon-modified separator, which may have advantages in terms of less weight content and better electrochemical performance for high-energy Li-S batteries over their roles as additives or S-host.

Herein, we demonstrate cobalt-molybdenum bimetallic carbide $\left(\mathrm{Co}_{3} \mathrm{Mo}_{3} \mathrm{C}\right)$ wrapped within mixed microporous/ low-range mesoporous carbon substrate as an efficient electrocatalyst to propel the polysulfide chemistry for highly efficient Li-S batteries via modifying the commercially available separator. The as-prepared carbonsupported $\mathrm{Co}_{3} \mathrm{Mo}_{3} \mathrm{C}$ nanocrystals have an average size of $3-5 \mathrm{~nm}$, and show much higher activity for promising polysulfide adsorption and conversion compared with the monometallic carbide $\mathrm{Mo}_{2} \mathrm{C}$. By employing the bimetallic carbide-based catalytic separator, denoted as $\mathrm{Co}_{3} \mathrm{Mo}_{3} \mathrm{C} /$ $\mathrm{PP}$, the Li-S cell shows high S utilization and long-lasting cycle life with a low capacity fade of $\sim 0.034 \%$ per cycle averaged upon 1000 cycles at $1 \mathrm{C}$ rate. The cell still delivers a maximum capacity of $851.4 \mathrm{~mA} \mathrm{~h} \mathrm{~g}^{-1}$ when the S- loading is up to $8.0 \mathrm{mg} \mathrm{cm}^{-2}$, corresponding to a pronounced areal capacity of $\sim 6.8 \mathrm{~mA} \mathrm{~h} \mathrm{~cm}^{-2}$. Impressively, the modified separator exhibits outstanding structural stability for reutilization, and the cycled $\mathrm{Co}_{3} \mathrm{Mo}_{3} \mathrm{C} / \mathrm{PP}$ separator enables the fresh $\mathrm{S} /$ Super $\mathrm{P}$ cathode to achieve remarkable electrochemical performance. The computational simulation further proved the bimetallic $\mathrm{Co}_{3} \mathrm{Mo}_{3} \mathrm{C}$, as well as the congeneric compounds $\mathrm{Ni}_{3} \mathrm{Mo}_{3} \mathrm{C}$ and $\mathrm{Fe}_{3} \mathrm{Mo}_{3} \mathrm{C}$, provided more binding sites to adsorb and catalyze the multiphase conversion of sulfur/polysulfide/ sulfide than that of the monometallic carbide $\mathrm{Mo}_{2} \mathrm{C}$.

\section{EXPERIMENTAL SECTION}

\section{Synthesis of bimetallic carbide samples}

In a typical procedure, cobalt(II) nitrate $(0.14 \mathrm{mmol})$ and ammonium molybdate $(0.02 \mathrm{mmol})$ were mixed with dicyandiamide $(0.2 \mathrm{~g})$, and the mixture was then heated to $900^{\circ} \mathrm{C}$ for $3 \mathrm{~h}$ under $\mathrm{Ar}$ atmosphere at a heating rate of $3^{\circ} \mathrm{C} \mathrm{min}{ }^{-1}$. The obtained black powder is carbonsupported $\mathrm{Co}_{3} \mathrm{Mo}_{3} \mathrm{C}$ bimetallic carbide. In addition, $\mathrm{Ni}_{3} \mathrm{Mo}_{3} \mathrm{C}$ and $\mathrm{Fe}_{3} \mathrm{Mo}_{3} \mathrm{C}$ samples were synthesized via the same procedure by replacing the Co-source with $\mathrm{Ni}$ source and Fe-source, respectively. As a control, the monometallic carbide $\mathrm{Mo}_{2} \mathrm{C}$ sample was also prepared from the mixture of only ammonium molybdate and dicyandiamide in the same process.

\section{Fabrication of the carbide-modified separator}

The as-prepared carbides were ground with Super P and polyvinylidene fluoride (PVDF) at the mass ratio of 7:2:1, and then the mixture was dispersed in $\mathrm{N}$-methly pyrrolidone (NMP) to obtain a homogeneous slurry. The slurry was coated on a commercial polypropylene (PP, Celgard 2400) separator via a typical doctor-blade casting method. The modified separator was dried in a vacuum oven at $80^{\circ} \mathrm{C}$. The average mass loading of the carbide in a separator (18 $\mathrm{mm}$ in diameter) was $\sim 0.5 \mathrm{mg} \mathrm{cm}^{-2}$.

\section{Material characterizations}

$\mathrm{X}$-ray diffraction (XRD, Bruker D8) analysis was performed to identify the phase of the samples in the $2 \theta$ range of $10^{\circ}-80^{\circ}$. X-ray photoelectron spectra (XPS, ThermalFisher Sci., Escalab250 Xi) were measured to confirm the surface chemical composition. Scanning electron microscopy (SEM, JSM 6700F) and transmission electron microscopy (TEM, JEM 2100) were used to manifest the microstructure and morphology of the assynthesized samples. Ultraviolet-visible (UV-Vis) spectra were measured by spectrophotometry (Cary 100). 


\section{Electrochemical measurements}

The cathode was fabricated by casting a slurry of commercial S powder, Super P and PVDF (6:3:1, w/w/w) onto Al foil. After being dried, the cathode film was punched into disks (12 $\mathrm{mm}$ in diameter) with a typical sulfur loading of $1.6 \mathrm{mg} \mathrm{cm}^{-2}$. Coin cells were assembled with metallic $\mathrm{Li}$ anode ( $16 \mathrm{~mm}$ in diameter) and the various as-obtained separators. The involved electrolyte was a mixture of $1 \mathrm{~mol} \mathrm{~L}^{-1}$ lithium bis(trifluoromethan-esulphonyl)imide (LiTFSI) and $2 \mathrm{wt} \% \mathrm{LiNO}_{3}$ in a solvent of 1,2-dimethoxyethane (DME) and 1,3-dioxolane (DOL) $(1: 1, v / v)$. The electrolyte/sulfur ratio was controlled as $10 \mu \mathrm{L} \mathrm{mg}^{-1}$. In terms of high sulfur loading of $8.0 \mathrm{~m} \mathrm{~cm}^{-2}$, the electrolyte/sulfur ratio was $6 \mu \mathrm{L} \mathrm{mg}^{-1}$. The discharge/charge tests were performed at various $\mathrm{C}$ rates $\left(1 \mathrm{C}=1675 \mathrm{~mA} \mathrm{~g}^{-1}\right)$ in the potential range of $1.7-2.8 \mathrm{~V}\left(v s . \mathrm{Li} / \mathrm{Li}^{+}\right)$. Cyclic voltammetry $(\mathrm{CV})$ was carried out at a scan rate of $0.1 \mathrm{mV} \mathrm{s}^{-1}$.

\section{Polysulfide adsorption and electrochemical kinetics tests}

$\mathrm{Li}_{2} \mathrm{~S}_{8}$ solution $\left(2 \mathrm{mmol} \mathrm{L}^{-1}\right)$ was obtained by adding stoichiometric $\mathrm{S}$ and $\mathrm{Li}_{2} \mathrm{~S}$ into the DME/DOL mixed solvent after sufficient reaction at $60^{\circ} \mathrm{C}$. For the polysulfide adsorption test, the completely dried sorbents were separately immersed into the $\mathrm{Li}_{2} \mathrm{~S}_{8}$ solution. Moreover, the powders were recovered from the $\mathrm{Li}_{2} \mathrm{~S}_{8}$ solution after full adsorption for XPS analysis.

To investigate the influence of the carbides on the electrochemical kinetics, symmetric polysulfide cells were assembled. Typically, various carbides were loaded onto graphite felt $(12 \mathrm{~mm})$ with the mass loading of $\sim 0.5 \mathrm{mg} \mathrm{cm}^{-2}$. Then, $20 \mu \mathrm{L}$ of $1 \mathrm{~mol} \mathrm{~L}^{-1} \mathrm{Li}_{2} \mathrm{~S}_{8}$-DME/DOL solution was dropped in each electrode before the coincell assembling. The symmetric cell was assembled with bare PP separator sandwiched by two identical carbide electrodes, and the above electrolyte $(20 \mu \mathrm{L})$ was used for $\mathrm{Li}-\mathrm{S}$ cell test. CV curves were recorded in the voltage range between -0.8 and $0.8 \mathrm{~V}$ at a scan rate of $5 \mathrm{mV} \mathrm{s}^{-1}$. Electrochemical impedance measurements were carried out in the frequency ranging from $0.1 \mathrm{~Hz}$ to $100 \mathrm{kHz}$ with the amplitude of $10 \mathrm{mV}$ using a PARSTAT 2273 workstation.

\section{First-principles calculations}

One hundred and thirty two atoms' supercell models of $\mathrm{Mo}_{2} \mathrm{C}$ surface and 188 atoms' supercell models of the three bimetallic carbide surfaces were constructed. Each model contains about 5 - $\AA$-thick surface layer and $15-\AA \AA$ thick vacuum layer to minimize the spurious interactions between the supercells and their images. The calculations were performed by using the Cambridge Serial Total Energy Package (CASTEP), based on the density functional theory (DFT) within the generalized gradient approximation (GGA). Ultrasoft pseudopotentials were used. Tkatchenko and Scheffler (TS) dispersion corrections were applied. The cutoff energy was $330 \mathrm{eV}$. The supercell is large enough that it is reasonable to use only gamma $k$ point. The atomic structures were relaxed until the forces on each atom were less than $0.01 \mathrm{eV} \AA^{-1}$ and the energy variation between two iterations was less than $2 \times 10^{-4} \mathrm{eV}$.

\section{RESULTS AND DISCUSSION}

As illustrated in Fig. 2a, we fabricated a series of carbide samples including the bimetallic carbides $\mathrm{M}_{3} \mathrm{Mo}_{3} \mathrm{C}$ $(\mathrm{M}=\mathrm{Co}, \mathrm{Ni}, \mathrm{Fe})$ and the monometallic carbide $\mathrm{Mo}_{2} \mathrm{C}$ via the simple pyrolysis of metallic precursors and dicyandiamide mixture. These bimetallic carbides $\left(\mathrm{M}_{3} \mathrm{Mo}_{3} \mathrm{C}, \mathrm{M}=\mathrm{Fe}, \mathrm{Co}, \mathrm{Ni}\right)$ show similar crystal lattice belonging to the same space group $(F d-3 m)$ with only little $2 \theta$ shifts [50,51] (Fig. S1), which is different from the $\mathrm{Fm}-3 m$ group of the $\mathrm{Mo}_{2} \mathrm{C}$ control sample (Fig. S2). The refined microstructure of $\mathrm{Co}_{3} \mathrm{Mo}_{3} \mathrm{C}$ sample is identified by TEM. Fig. 2b, $c$ demonstrate that uniform monodisperse $\mathrm{Co}_{3} \mathrm{Mo}_{3} \mathrm{C}$ nanocrystals with the average diameter of 3-5 nm appear as black dots. The $\mathrm{Co}_{3} \mathrm{Mo}_{3} \mathrm{C}$ nanocrystals were wrapped uniformly by carbon layer, instead of being exposed on the carbon surface. The similar microstructure can also be observed in other samples (Fig. S3).

The carbon substrate exhibits atypical porous structure with abundant micropores of $<1 \mathrm{~nm}$ and low-range mesopores of 3.3 and $5.8 \mathrm{~nm}$ (Fig. S4), which benefits not only for physically confining the dissolution of the polysulfides, but also for smooth electrolyte penetration and fast ion transfer [29]. These carbon scaffolds also prevent the agglomeration of $\mathrm{Co}_{3} \mathrm{Mo}_{3} \mathrm{C}$ nanocrystals. The contents of carbon scaffolds and $\mathrm{Co}_{3} \mathrm{Mo}_{3} \mathrm{C}$ are $52 \mathrm{wt} \%$ and $48 \mathrm{wt} \%$, respectively, as identified by thermogravimetric analyzer (TGA, Fig. S5). High-resolution TEM (HRTEM) images (Fig. 2d, e) demonstrate the clear fringes with an interplanar spacing $(d)$ of $\sim 0.21 \mathrm{~nm}$, which matchs well with the (511) lattice plane of cubic $\mathrm{Co}_{3} \mathrm{Mo}_{3} \mathrm{C}$ [52]. Fig. 2f shows the scanning tunneling electron microscopy (STEM) image and energy dispersive spectroscopy (EDS) elemental mapping, suggesting the coexistence and the uniform distribution of elements C, $\mathrm{N}, \mathrm{Co}$ and Mo.

The chemical interaction mechanism between the carbides and polysulfide species was analyzed by XPS for the 
a

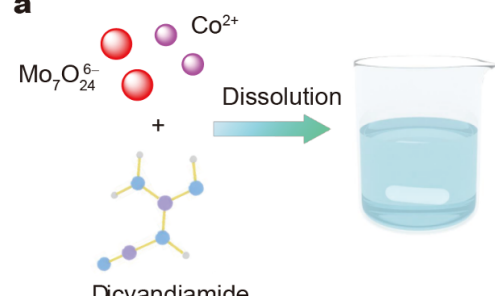

Dicyandiamide
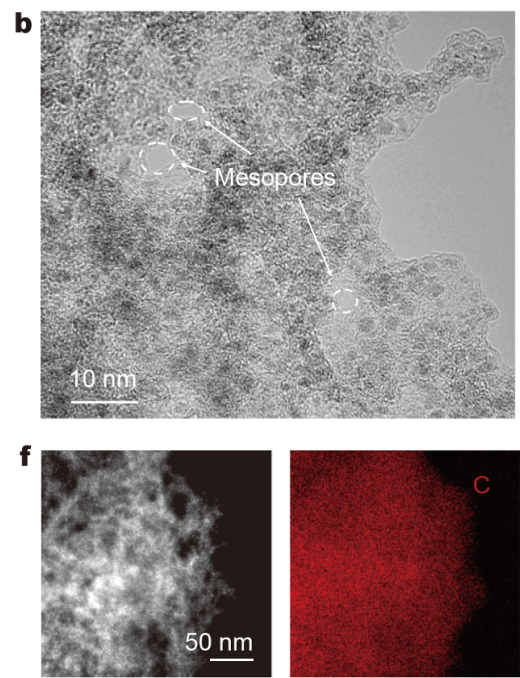
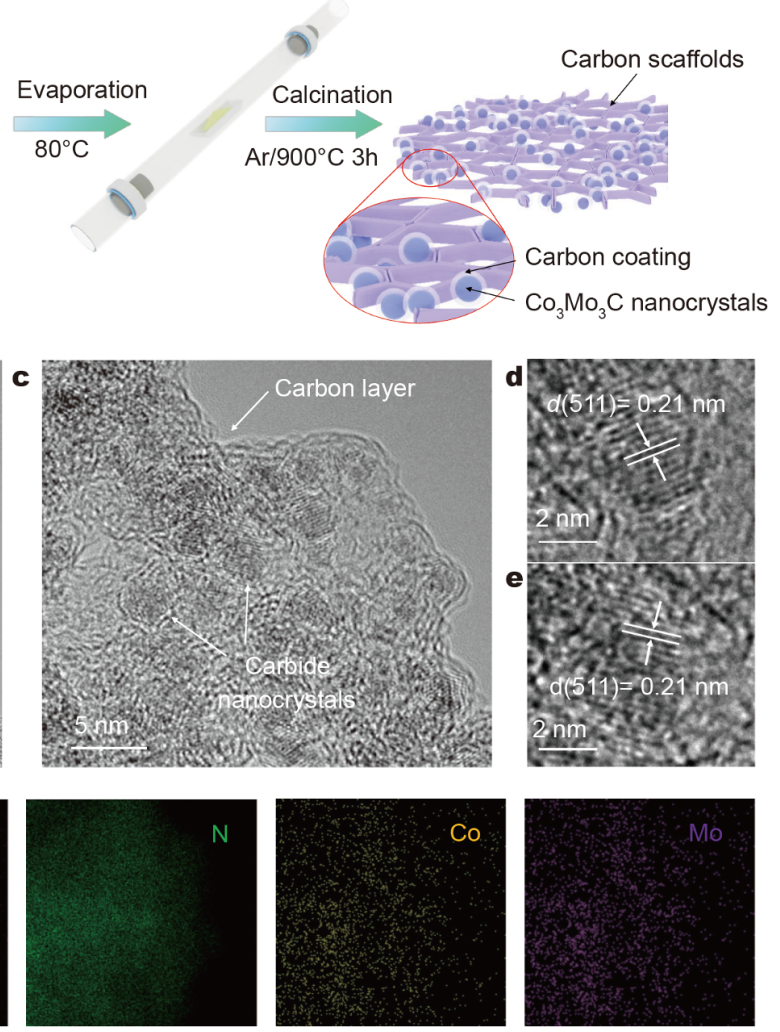

Figure 2 Schematic illustration of synthesis and morphological characterization. (a) Schematic illustration of the synthesis of $\mathrm{Co}_{3} \mathrm{Mo}_{3} \mathrm{C}$ sample. $(\mathrm{b}, \mathrm{c})$ TEM images, and (d, e) HRTEM images of $\mathrm{Co}_{3} \mathrm{Mo}_{3} \mathrm{C}$ sample. (f) STEM image and EDS elemental mapping.

carbides before and after contacting with $\mathrm{Li}_{2} \mathrm{~S}_{8}$. The Co $2 \mathrm{p}$ spectrum (Fig. 3a) of original $\mathrm{Co}_{3} \mathrm{Mo}_{3} \mathrm{C}$ shows the presence of both $\mathrm{Co}^{2+}$ and $\mathrm{Co}^{3+}$ due to the inevitable surface oxidation. After interacting with polysulfides, blueshifts of both $\mathrm{Co}^{2+} 2 \mathrm{p}_{3 / 2}$ peak (from 781.1 to $781.5 \mathrm{eV}$ ) and $\mathrm{Co}^{3+} 2 \mathrm{p}_{3 / 2}$ peak (from 783.6 to $784.0 \mathrm{eV}$ ) are observed $[53,54]$. It can be further confirmed by the reduction of high-valence Co $\left(\mathrm{Co}^{3+}\right)$ after interacting with $\mathrm{Li}_{2} \mathrm{~S}_{8}$. Consistent with the Co $2 \mathrm{p}$ analysis, both the blueshifts of peaks and the reduction of high-valence Mo are also observed in the refined Mo $3 \mathrm{~d}$ spectrum (Fig. 3b) due to the chemical interaction with polysulfides $[55,56]$. In addition, apart from the original peaks of bridging $\mathrm{S}\left(\mathrm{S}_{\mathrm{B}}{ }^{0}\right.$, $161.6 \mathrm{eV})$ and terminal $\mathrm{S}\left(\mathrm{S}_{\mathrm{T}}^{-1}, 163.4 \mathrm{eV}\right)$ in $\mathrm{Li}_{2} \mathrm{~S}_{8}$ species, extra peaks assigned to thiosulfate $(167.2 \mathrm{eV})$ and polythionate $(168.2 \mathrm{eV})$ appear in the $\mathrm{S} 2 \mathrm{p}$ spectrum of $\mathrm{Co}_{3} \mathrm{Mo}_{3} \mathrm{C}-\mathrm{Li}_{2} \mathrm{~S}_{8}$ in Fig. 3c. The thiosulfate and polythionate components show electrochemical activity to be favorably reduced to $\mathrm{Li}_{2} \mathrm{~S}$ and regenerated upon charging [57]. The oxidation of $S$ species is in accord with the reduction of high-valence of both Co and Mo, indicating the strong chemical metal-S bonds. Notably, the $\mathrm{S}_{\mathrm{T}}^{-1}$ peak in the $\mathrm{Co}_{3} \mathrm{Mo}_{3} \mathrm{C}-\mathrm{Li}_{2} \mathrm{~S}_{8}$ sample is higher than the $\mathrm{S}_{\mathrm{B}}{ }^{0}$ peak, which is totally different from that of pure $\mathrm{Li}_{2} \mathrm{~S}_{8}$ (Fig. S6), suggesting the transformation of long-chain $\mathrm{Li}_{2} \mathrm{~S}_{8}$ to short chain polysulfide or sulfide on $\mathrm{Co}_{3} \mathrm{Mo}_{3} \mathrm{C}$ surface. As a control experiment, the shape of $\mathrm{S}_{\mathrm{B}}{ }^{0}$ and $\mathrm{S}_{\mathrm{T}}{ }^{-1}$ peaks in $\mathrm{Mo}_{2} \mathrm{C}-\mathrm{Li}_{2} \mathrm{~S}_{8}$ sample (Fig. $3 \mathrm{c}$ ) is very similar to pure $\mathrm{Li}_{2} \mathrm{~S}_{8}$, indicating no obvious polysulfide conversion on $\mathrm{Mo}_{2} \mathrm{C}$ surface. These findings demonstrate more valence states and more binding sites with polysulfides in bimetallic carbides than monometallic carbide. Furthermore, the refined $\mathrm{N} 1 \mathrm{~s}$ spectrum (Fig. S7) confirms the presence of doped $\mathrm{N}$ elements $(\sim 2.8 \mathrm{wt} \%)$ with typical pyridinic, pyrrolic and graphitic structures in the carbonsupported $\mathrm{Co}_{3} \mathrm{Mo}_{3} \mathrm{C}$ sample, consistent with the $\mathrm{EDS}$ results in Fig. 2f. The doped $\mathrm{N}$ elements induced by the dicyandiamide precursor can further enhance the polysulfide confinement of the sample $[58,59]$. Hence, the effective chemical adsorption and conversion of polysulfides on $\mathrm{Co}_{3} \mathrm{Mo}_{3} \mathrm{C}$ surface benefit the surface reaction redox. Furthermore, visual adsorption test (inset of Fig. 3d and Fig. S8) confirms the excellent polysulfideadsorption ability of bimetallic carbide samples by the 


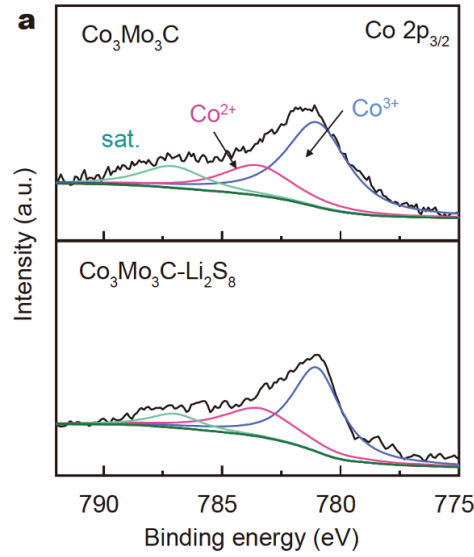

d

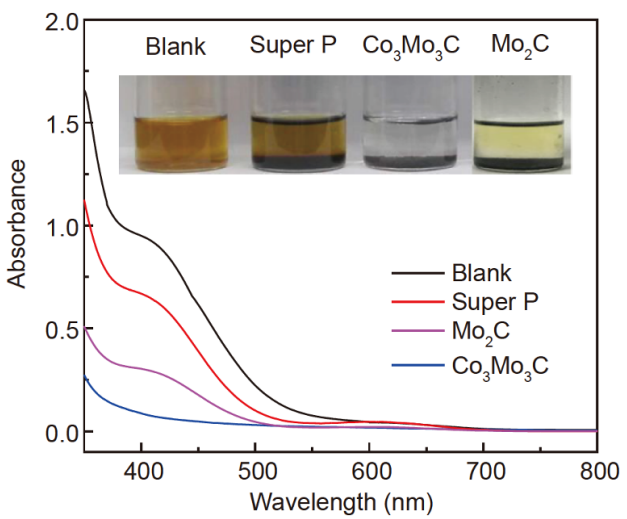

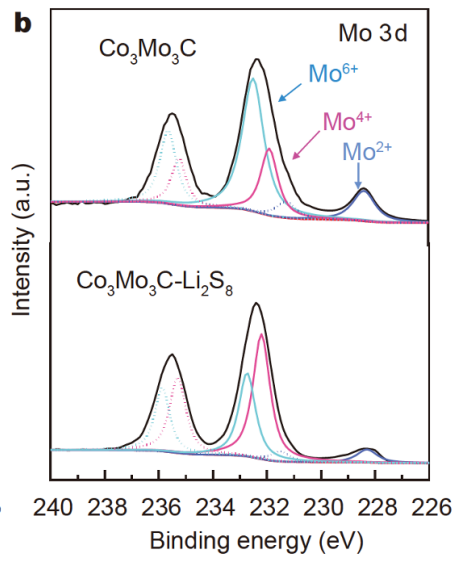

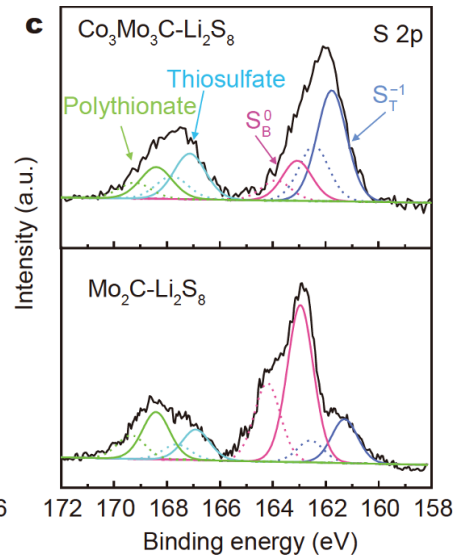

e

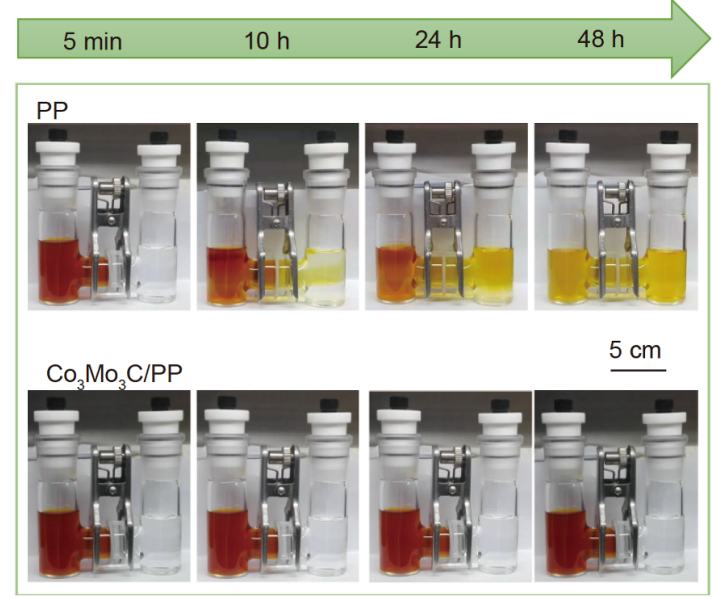

Figure 3 Chemical interaction and adsorption for lithium polysulfide. XPS spectra for (a) Co $2 p_{3 / 2}$, (b) Mo $3 d$, and (c) S $2 p$ of the carbide adsorbed with long-chain $\mathrm{Li}_{2} \mathrm{~S}_{8}$. (d) UV-Vis spectra of polysulfide solution upon adsorption by different sorbents. (e) H-type cells for the polysulfide diffusion with PP (up) and modified $\mathrm{Co}_{3} \mathrm{Mo}_{3} \mathrm{C} / \mathrm{PP}$ separator (down).

colorless $\mathrm{Li}_{2} \mathrm{~S}_{8}$ solution containing bimetallic carbides after full adsorption, which is also validated by the negligible absorbance in UV-Vis spectra [60] (Fig. 3d). To visually demonstrate the role of the carbide-modified separator in restraining the polysulfide shuttle, H-type glass-cells were assembled as shown in Fig. 3e with different solutions filled in two chambers. The polysulfides can diffuse towards to the other side through the bare PP separator. By contrast, the cell separated by $\mathrm{Co}_{3} \mathrm{Mo}_{3} \mathrm{C} / \mathrm{PP}$ separator can maintain the colorless right chamber even after $48 \mathrm{~h}$, vividly suggesting the significantly restrained polysulfide shuttle.

As shown in Fig. 4a, the modified separator with a large area can be easily obtained via a convenient slurry-coating method. SEM images of the $\mathrm{Co}_{3} \mathrm{Mo}_{3} \mathrm{C} / \mathrm{PP}$ separator surface (Fig. S9) show the coating layer combing the $\mathrm{Co}_{3} \mathrm{Mo}_{3} \mathrm{C}$ sample and Super $\mathrm{P}$ particles on PP separator surface, covering its typical porous structure (Fig. S10). The cross-section SEM image in Fig. $4 \mathrm{~b}$ shows a coating layer with a thickness of $\sim 8 \mu \mathrm{m}$ with uniform distribution of C, Co, Mo elements. Notably, the carbide sample exhibits a favorable adhesion to PP separator, leading to excellent mechanical properties of the modified separator, as illustrated by the folding/unfolding test (Fig. 4c and Fig. S11). The puncture test results (Fig. 4d) clearly demonstrate the higher puncture strength of the $\mathrm{Co}_{3} \mathrm{Mo}_{3} \mathrm{C}$ / PP separator, which makes the modified separator with great potential in enduring the spiculate $\mathrm{Li}$ dendrites. Fig. $4 \mathrm{e}$, $\mathrm{f}$ show the contact angle of the electrolyte drop on the separator surface, and the $\mathrm{Co}_{3} \mathrm{Mo}_{3} \mathrm{C} / \mathrm{PP}$ separator exhibits a much lower contact angle than that of PP separator, indicating better electrolyte wettability. Therefore, the coated side facing the $\mathrm{S}$ cathode in a Li-S battery could restrain the polysulfide shuttle, catalyze the polysulfide conversion, and stabilize the Li anode.

The electrode/polysulfide interfacial electrocatalytic activity was further probed by symmetric $\mathrm{Li}_{2} \mathrm{~S}_{8}$ cells with polysulfide electrolyte using different electrodes. As 
a

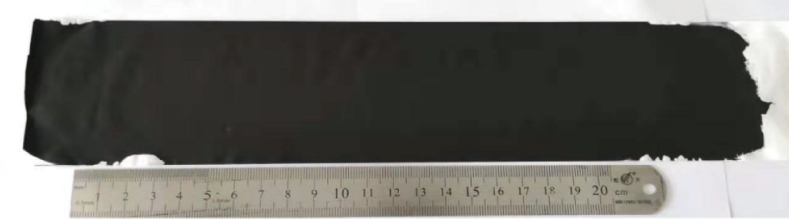

c

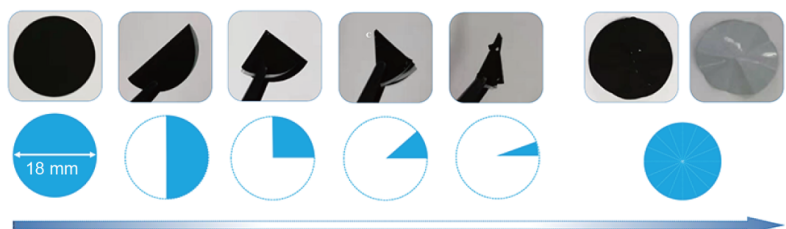

d

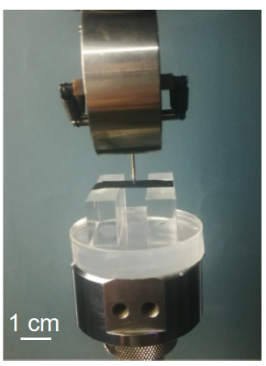

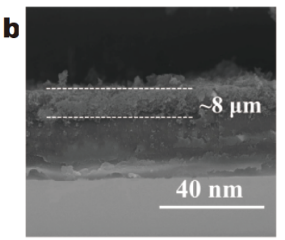
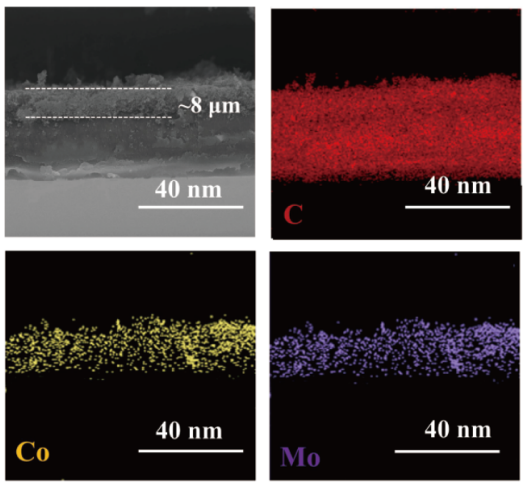

e

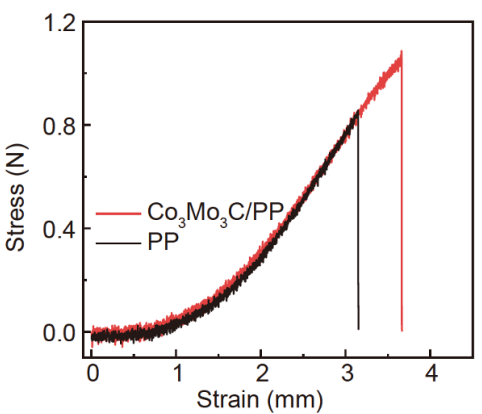

$\mathrm{Co}_{3} \mathrm{Mo}_{3} \mathrm{C} / \mathrm{PP}$

$5^{\circ}$

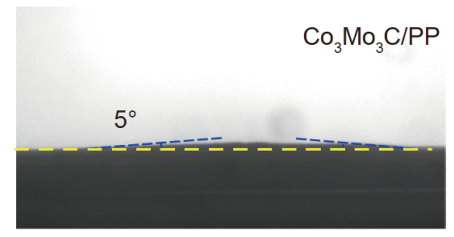

f

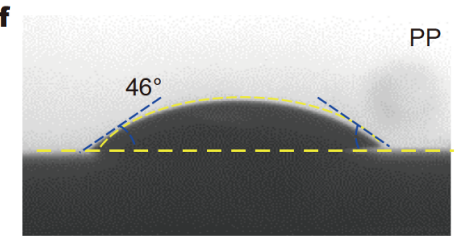

Figure 4 Property measurements of the modified $\mathrm{Co}_{3} \mathrm{Mo}_{3} \mathrm{C} / \mathrm{PP}$ separator. (a) Photo of $\mathrm{Co}_{3} \mathrm{Mo}_{3} \mathrm{C} / \mathrm{PP}$ separator. (b) Cross-sectional SEM image and EDS elemental mapping. (c) Folding test. (d) Photo and results of puncture test. Contact angle of the electrolyte drop on (e) $\mathrm{Co}_{3} \mathrm{Mo}_{3} \mathrm{C} / \mathrm{PP}$, and (f) bare PP surface.

shown in Fig. 5a, the redox current in the CV curve of the $\mathrm{Co}_{3} \mathrm{Mo}_{3} \mathrm{C}$ electrode, as well as the other bimetallic carbide electrodes (Fig. S12), is much higher than that of the $\mathrm{Mo}_{2} \mathrm{C}$ electrode. At the same time, the charge-transfer resistances in electrochemical impedance spectroscopy (EIS) plots (Fig. S13) show an opposite tendency, which means the fast interfacial reaction kinetics on $\mathrm{Co}_{3} \mathrm{Mo}_{3} \mathrm{C}$ electrode surface. The in-depth insight of interfacial reaction kinetics in practical Li-S batteries was further understood by assembling coin cells with the carbidemodified separator as a catalytic membrane. The typical S-loading is controlled as $\sim 1.6 \mathrm{mg} \mathrm{cm}^{-2}$ in the S/Super P cathode. $\mathrm{CV}$ curve (Fig. 5b) of the as-assembled cell with the $\mathrm{Co}_{3} \mathrm{Mo}_{3} \mathrm{C} / \mathrm{PP}$ separator displays two cathodic peaks at 2.06 and $2.33 \mathrm{~V}$, ascribed to the formation of long-chain polysulfides and insoluble $\mathrm{Li}_{2} \mathrm{~S}_{2} / \mathrm{Li}_{2} \mathrm{~S}$, respectively, and two partially overlapped anodic peaks related to the following oxidation process $[61,62]$. In comparison with bare PP separator, the cell with $\mathrm{Co}_{3} \mathrm{Mo}_{3} \mathrm{C} / \mathrm{PP}$ separator exhibits much higher redox currents and lower polar- ization, indicating the accelerated redox kinetics of polysulfide redox reactions by the $\mathrm{Co}_{3} \mathrm{Mo}_{3} \mathrm{C}$.

Fig. $5 \mathrm{c}$ illustrates the rate capabilities of the cells with different separators. The $\mathrm{Co}_{3} \mathrm{Mo}_{3} \mathrm{C}$ catalytic layer enables the $\mathrm{S}$ cathode to realize superior rate capability with high specific capacities of 1284, 1036, 909, 840, 759, $633 \mathrm{~mA} \mathrm{~h} \mathrm{~g}^{-1}$ at $0.1,0.2,0.5,1,2$, and $5 \mathrm{C}$, while the capacities of the cells with $\mathrm{Mo}_{2} \mathrm{C} / \mathrm{PP}$ or bare $\mathrm{PP}$ separator suffer from inferior capabilities at high C-rates. The capacities drop, especially for the one with bare PP, should result from the severe shrinkage or even loss of low discharge plateaus (Fig. S14) due to the sluggish redox kinetics. As expected, the $\mathrm{Co}_{3} \mathrm{Mo}_{3} \mathrm{C}$ catalytic layer enables high $\mathrm{S}$ utilization and moderate shrinkage of discharge plateaus (Fig. S15) due to the multiple binding sites of polysulfides to promote redox reaction kinetics. The long-term discharge/charge test shows that the $\mathrm{Co}_{3} \mathrm{Mo}_{3} \mathrm{C} /$ PP separator enables better cycle stability with a low capacity fade ratio of $\sim 0.16 \%$ per cycle averaged over 200 cycles at $0.1 \mathrm{C}$ (Fig. 5d), compared with that of the cell 

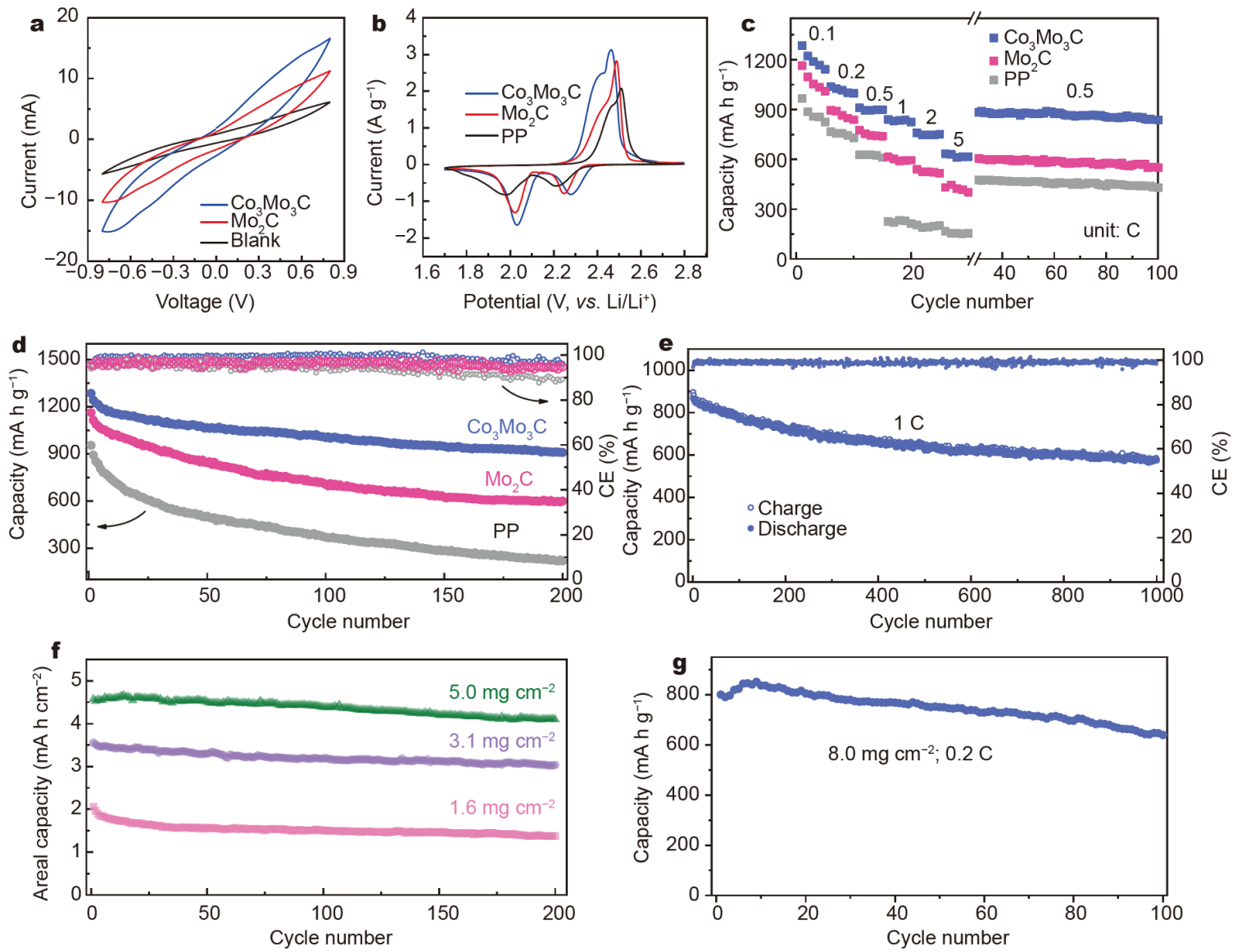

Figure 5 Electrochemical performance of Li-S cells. CV curves of (a) symmetric $\mathrm{Li}_{2} \mathrm{~S}_{8}$ cells and (b) Li-S cells with different separators. (c) Rate capability at different rates. (d) Cycle stability at $0.1 \mathrm{C}$ of the cathodes (sulfur loading of $\sim 1.6 \mathrm{mg} \mathrm{cm}^{-2}$ ) with different separators. (e) Cycle stability at $1 \mathrm{C}$ of the cathode with $\mathrm{Co}_{3} \mathrm{Mo}_{3} \mathrm{C} / \mathrm{PP}$ separator. Cycle performance of the cathodes with $\mathrm{Co}_{3} \mathrm{Mo}_{3} \mathrm{C} / \mathrm{PP}$ separator under high sulfur loadings at (f) $0.1 \mathrm{C}$, and $(\mathrm{g}) 0.2 \mathrm{C}$.

employing $\mathrm{Mo}_{2} \mathrm{C} / \mathrm{PP}$ or bare PP separator. It is because that $\mathrm{Co}_{3} \mathrm{Mo}_{3} \mathrm{C} / \mathrm{PP}$ separator can effectively restrain the polysulfide shuttle by strong chemical adsorption and physical barrier, and show higher activity to catalyze the polysulfide conversion than $\mathrm{Mo}_{2} \mathrm{C} / \mathrm{PP}$. Moreover, such an improvement is further verified by the long-term discharge/charge tests at a high rate of $1 \mathrm{C}$ in Fig. 5e. The $\mathrm{Co}_{3} \mathrm{Mo}_{3} \mathrm{C} / \mathrm{PP}$ separator enables $\mathrm{S}$ cathode to achieve high coulombic efficiency and superior cycle stability up to 1000 cycles with low capacity decay rate of only $0.034 \%$ per cycle, while the cell with bare PP separator suffers rapid capacity decay from 639 to $237 \mathrm{~mA} \mathrm{~h} \mathrm{~g}^{-1}$ and lower coulombic efficiency (Fig. S16).

To further verify the high activity of the carbide electrocatalyst for enhanced kinetics, the cathodes with high S-loadings were tested. The cells employing $\mathrm{Co}_{3} \mathrm{Mo}_{3} \mathrm{C} / \mathrm{PP}$ separator exhibit maximum areal capacity $\sim 4.8 \mathrm{~mA} \mathrm{~h} \mathrm{~cm}^{-2}\left(959 \mathrm{~mA} \mathrm{~h} \mathrm{~g}^{-1}\right)$ with the S-loading of $\sim 5.0 \mathrm{mg} \mathrm{cm}^{-2}$ at $0.1 \mathrm{C}$ (Fig. 5f). Excellent cycle stabilities can be realized with high capacity retention even after 200 cycles for the $S$ cathodes with different S-loadings. Meanwhile, when accumulating the S-loading up to $8.0 \mathrm{~m} \mathrm{~cm}^{-2}$, a maximum specific capacity of $851.4 \mathrm{~mA} \mathrm{~h} \mathrm{~g}^{-1}$, corresponding to a $6.8 \mathrm{~mA} \mathrm{~h} \mathrm{~cm}^{-2}$ areal capacity, can be achieved at $0.2 \mathrm{C}$ with a electrolyte/sulfur ratio of $6 \mu \mathrm{L} \mathrm{g}^{-1}$. Moreover, such enhanced performances including high capacity and excellent cycle stability are comparable to the reported Li-S systems with modified separators so far (Table S1). The results suggest the potential of the catalytic-modified separator for highenergy-density Li-S batteries. In fact, the significant enhancement on the electrochemical performance is related to the multiple chemical binding sites toward polysulfides on bimetallic carbides; and the strong chemical interaction can significantly control the shuttle effect and enhance the redox kinetics of polysulfide chemistry, the 
benefits are reflected by high capacity and stable S cathodes even with high S-loadings.

To comprehensively reveal the superiority of the carbide catalytic material for actual Li-S batteries, some necessary post-cycling tests were carried out. As shown in Fig. 6a, the bare PP separator shows a brown-yellow appearance due to the trapped "dead" polysulfides with no electrochemical activity, which is also confirmed by the yellow solution after soaking the cycled PP in DME solvent. On the other hand, the confined polysulfides by $\mathrm{Co}_{3} \mathrm{Mo}_{3} \mathrm{C}$ sample catalyze redox reaction during cycling as evidenced by the clear DME solvent soaked with $\mathrm{Co}_{3} \mathrm{Mo}_{3} \mathrm{C} / \mathrm{PP}$ separator. Furthermore, the $\mathrm{Co}_{3} \mathrm{Mo}_{3} \mathrm{C} / \mathrm{PP}$ separator exhibits intact surface after repeated cycles, indicating the promising adhesion of $\mathrm{Co}_{3} \mathrm{Mo}_{3} \mathrm{C}$ sample to PP separator surface. Furthermore, XRD patterns of
$\mathrm{Co}_{3} \mathrm{Mo}_{3} \mathrm{C}$ after cycling in Fig. 6b clearly confirm the unaltered crystal structure with characteristic diffraction peaks. And the TEM image (Fig. 6c) also demonstrates that the carbide nanocrystals are still wrapped in the carbon substrate. HRTEM image in Fig. 6d further confirms the clear lattice fringes with a $d$ value of $\sim 0.21 \mathrm{~nm}$, which matches well with the (511) lattice plane of $\mathrm{Co}_{3} \mathrm{Mo}_{3} \mathrm{C}$. Notably, the lattice fringe with $d=0.34 \mathrm{~nm}$ can be assigned to the (002) plane of graphitic carbon in the carbide sample, which can also be referred to Fig. 6e. These results vividly indicate the desirable structure stability of both $\mathrm{Co}_{3} \mathrm{Mo}_{3} \mathrm{C}$ material and $\mathrm{Co}_{3} \mathrm{Mo}_{3} \mathrm{C} / \mathrm{PP}$ separator during long-term electrochemical cycles.

The polysulfide shuttling not only leads to the rapid capacity loss of S cathode, but also causes the severe damage to the surface morphology of $\mathrm{Li}$ anode, which goes $\mathbf{a}$
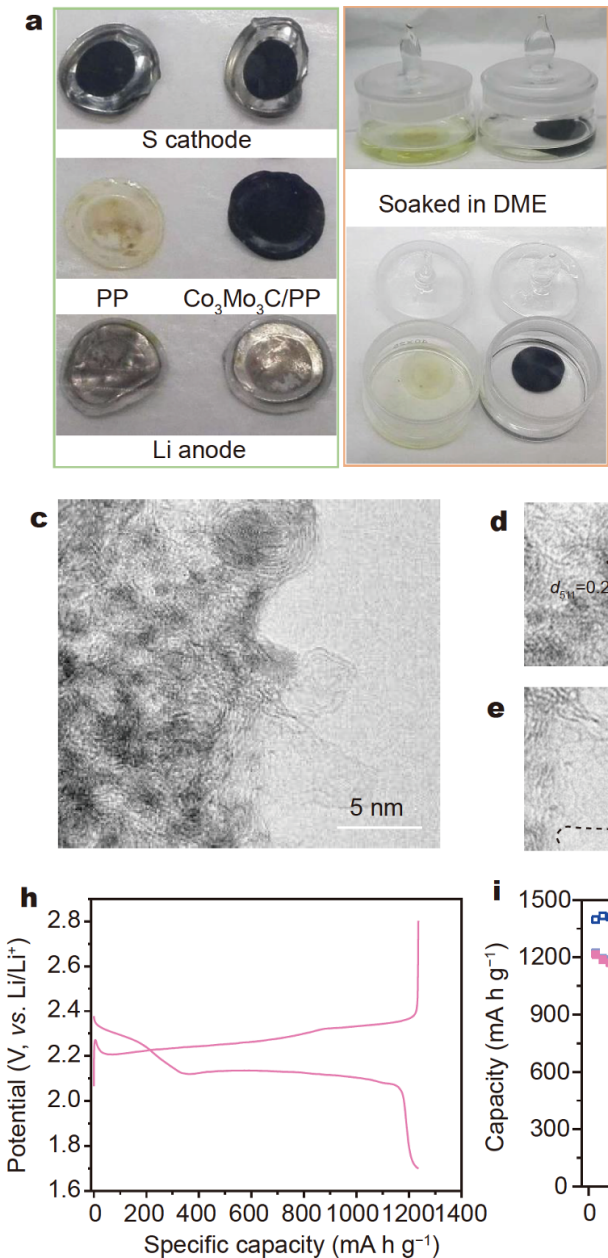
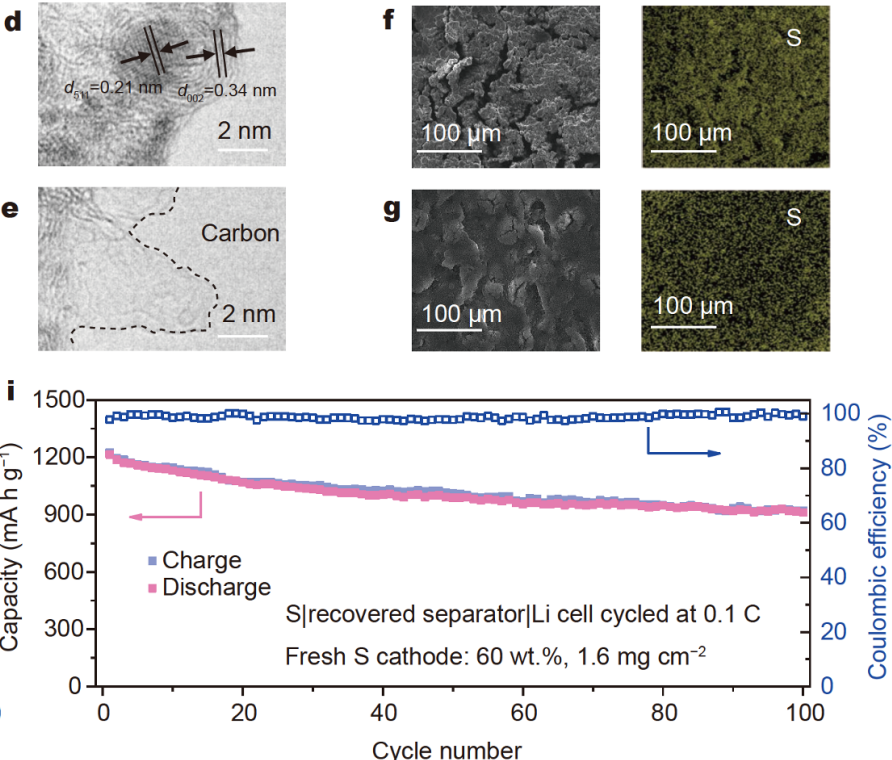

Figure 6 Post-cycle characterization. (a) Photos of disassembled Li-S cells with different separators. (b) XRD patterns of the Co $\mathrm{Mo}_{3} \mathrm{C} / \mathrm{PP}$ separator before and after cycling. (c-e) TEM and HRTEM images of cycled $\mathrm{Co}_{3} \mathrm{Mo}_{3} \mathrm{C}$ sample; SEM images and EDS elemental S mapping of cycled Li anode for the cells with (f) bare PP separator, and $(\mathrm{g}) \mathrm{Co}_{3} \mathrm{Mo}_{3} \mathrm{C} / \mathrm{PP}$ separator. Electrochemical performance of the fresh sulfur cathode $\left(\sim 1.6 \mathrm{mg} \mathrm{cm}{ }^{-2}\right)$ with the cycled $\mathrm{Co}_{3} \mathrm{Mo}_{3} \mathrm{C} / \mathrm{PP}$ separator at $0.1 \mathrm{C}$ : (h) initial discharge/charge curve, (i) cycle stability. 
against to the cycle stability of the cell in turn $[63,64]$. The polysulfide shuttle in the cell with a bare PP separator leads to a damaged surface with cracks and severe deposition of insoluble $\mathrm{Li}_{2} \mathrm{~S}_{2} / \mathrm{Li}_{2} \mathrm{~S}$ (Fig. $6 \mathrm{f}$ and Fig. S17). On the contrary, as seen in Fig. $6 \mathrm{~g}$, the $\mathrm{Co}_{3} \mathrm{Mo}_{3} \mathrm{C} / \mathrm{PP}$ separator acts as an effective polysulfide barrier to protect well the $\mathrm{Li}$ anode from polysulfide corrosion and reduce the $\mathrm{Li}_{2} \mathrm{~S}_{2} / \mathrm{Li}_{2} \mathrm{~S}$ deposition.

Further, the reutilization of the robust $\mathrm{Co}_{3} \mathrm{Mo}_{3} \mathrm{C} / \mathrm{PP}$ separator was demonstrated. Li-S cells were assembled using the recycled $\mathrm{Co}_{3} \mathrm{Mo}_{3} \mathrm{C} / \mathrm{PP}$ separator, fresh $\mathrm{S}$ cathode with the S-loading of $1.6 \mathrm{mg} \mathrm{cm}^{-2}$, and fresh $\mathrm{Li}$ anode. As shown in Fig. $6 \mathrm{~h}$, the fresh Li-S cell shows representative discharge/charge curves with two potential platforms and delivers a high initial specific capacity of $1251 \mathrm{~mA} \mathrm{~h} \mathrm{~g}^{-1}$ at 0.1 C. More impressively, excellent cycle stability can be realized with high capacity of $905 \mathrm{~mA} \mathrm{~h} \mathrm{~g}^{-1}$ after 100 cycles (Fig. 6i). We believe that the satisfying reutilization of the modified separators is of great significance for high-performance and low-cost Li-S batteries. In addition, these results evidently demonstrate the superiority of bimetallic carbide in controlling polysulfide shuttling and catalyzing the redox kinetics, thus realizing the improved electrochemical performance of $\mathrm{S}$ cathodes.

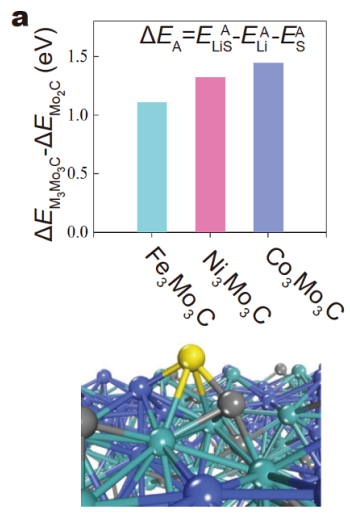

$\mathrm{S}$ on $\mathrm{M}_{3} \mathrm{Mo}_{3} \mathrm{C}$ (511)

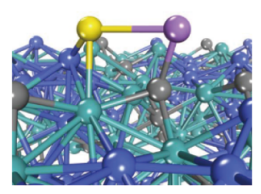

LiS on $\mathrm{M}_{3} \mathrm{Mo}_{3} \mathrm{C}$ (511)

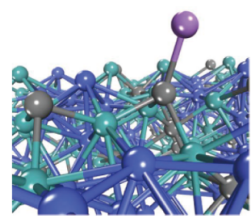

Li on $\mathrm{M}_{3} \mathrm{Mo}_{3} \mathrm{C}(511)$

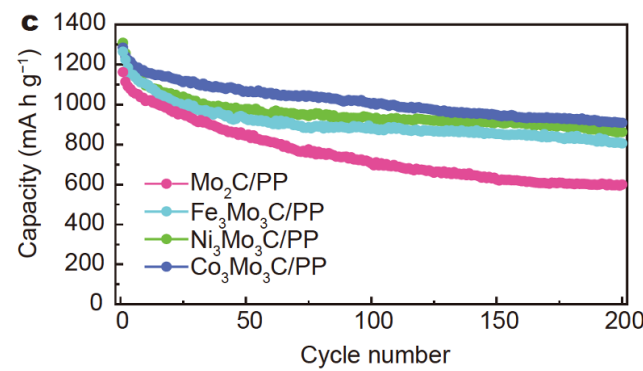

To investigate the performance difference between $\mathrm{Mo}_{2} \mathrm{C}$ and $\mathrm{M}_{3} \mathrm{Mo}_{3} \mathrm{C}$, first-principles calculations were performed on the adsorptions of short-chain lithium sulfides $\mathrm{LiS}$ as well as single $\mathrm{Li}$ and $\mathrm{S}$ atoms on these carbide surfaces. (111) and (511) surfaces of $\mathrm{Mo}_{2} \mathrm{C}$ and $\mathrm{M}_{3} \mathrm{Mo}_{3} \mathrm{C}$ (Fig. S18), respectively, were used, according to the XRD measurements. The adsorption sites for $\mathrm{Li}$ and $\mathrm{S}$ atoms were chosen to be near $\mathrm{C}$ and metallic atoms, respectively, to maximize the tendencies of adsorptions. The adsorption energy of $\mathrm{X}$ on surface $\mathrm{A}, E_{\mathrm{X}}{ }^{\mathrm{A}}$, was calculated according to

$E_{\mathrm{X}}{ }^{\mathrm{A}}=E_{\mathrm{X}^{*}}-E^{*}-E_{\mathrm{X}}$,

where $E_{\mathrm{X}^{*}}$ is the total energy of the surface with adsorbate $\mathrm{X}, E^{*}$ is the total energy of the bare surface and $E_{\mathrm{X}}$ is the total energy of isolated $\mathrm{X}$. More negative (or less positive) $E_{\mathrm{X}}{ }^{\mathrm{A}}$ value indicates a stronger adsorption tendency. We also defined $\Delta E_{\mathrm{A}}$ as the difference between the adsorption energy of LiS and the sum of those of single Li and $\mathrm{S}$ atoms on surface $\mathrm{A}$, i.e.,

$\Delta E_{\mathrm{A}}=E_{\mathrm{LiS}}{ }^{\mathrm{A}}-E_{\mathrm{Li}}{ }^{\mathrm{A}}-E_{\mathrm{S}}{ }^{\mathrm{A}}$,

where $\Delta E_{\mathrm{A}}$ reflects the tendency of the decomposition of $\mathrm{LiS}$ molecule to $\mathrm{Li}$ and $\mathrm{S}$ atoms upon its adsorption to the surface and a more positive (or less negative) value in-
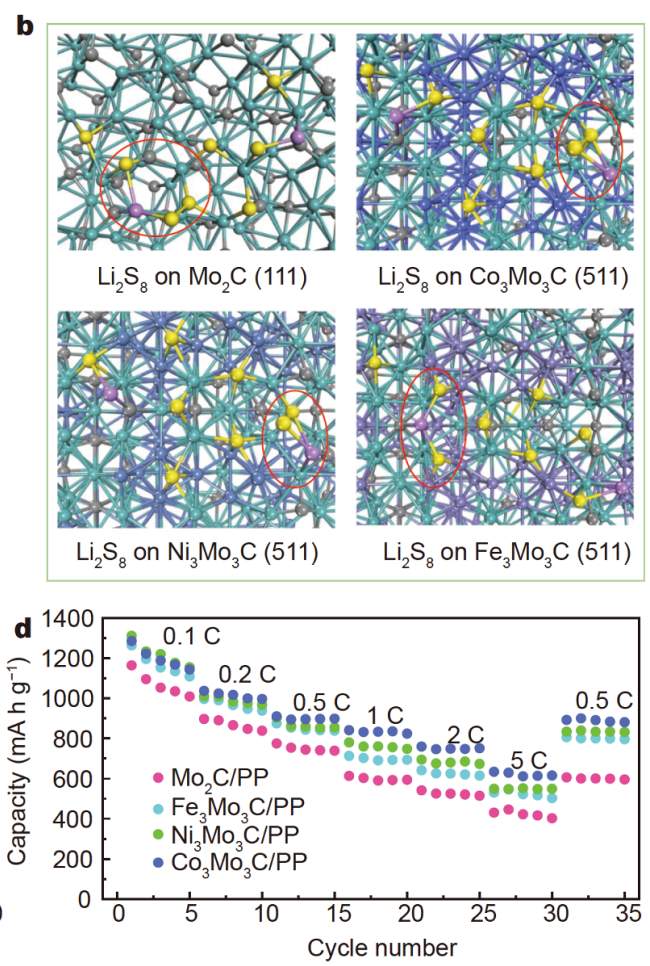

Figure 7 First-principles calculation results. Adsorption of (a) short-chain LiS, S and Li (yellow, S; pink, Li; grey, C; green, Mo; blue, M=Co, Ni, Fe), and (b) long-chain $\mathrm{Li}_{2} \mathrm{~S}_{8}$ on $\mathrm{Mo}_{2} \mathrm{C}$ and $\mathrm{M}_{3} \mathrm{Mo}_{3} \mathrm{C}$ surfaces (yellow, $\mathrm{S}$; pink, Li; grey, C; green, Mo; blue, Co; silver, Ni/Fe). (c) Cycle stability at $0.1 \mathrm{C}$, and (d) rate capability at different rates of the $\mathrm{S} /$ Super $\mathrm{P}$ cathodes (sulfur loading of $\sim 1.6 \mathrm{mg} \mathrm{cm}{ }^{-2}$ ) with $\mathrm{Mo}_{2} \mathrm{C} / \mathrm{PP}$ and $\mathrm{M}_{3} \mathrm{Mo}_{3} \mathrm{C} / \mathrm{PP}$ separators. 
dicates stronger decomposition tendency. Accordingly, all the calculated $\Delta E_{\mathrm{M}_{3} \mathrm{Mo}_{3} \mathrm{C}}$ values are larger than $\Delta E_{\mathrm{Mo}_{2} \mathrm{C}}$ by 1.1-1.4 eV, as concluded in Fig. 7a, indicating that bimetallic carbide surfaces can further enhance the catalytic decomposition of the lithium sulfides compared with $\mathrm{Mo}_{2} \mathrm{C}$ surface.

We also simulated the adsorption of long-chain lithium polysulfide $\mathrm{Li}_{2} \mathrm{~S}_{8}$ on these surfaces. The calculated adsorption energies show that the adsorptions on bimetallic carbide surfaces are also more preferred than that on $\mathrm{Mo}_{2} \mathrm{C}$ surface. In addition, as shown in Fig. $7 \mathrm{~b}$, we note that $\mathrm{Li}_{2} \mathrm{~S}_{8}$ adsorbate is decomposed to short-chain $\mathrm{LiS}$, $\mathrm{LiS}_{2}$ and single $\mathrm{S}$ atoms on all three bimetallic carbide surfaces, whereas longer-chain $\mathrm{LiS}_{3}$ still remains on $\mathrm{Mo}_{2} \mathrm{C}$ surface, in consistence with the enhanced catalytic decomposition effects of the bimetallic carbide surfaces as previously discussed. The better performance of $\mathrm{Co}_{3} \mathrm{Mo}_{3} \mathrm{C}$ compared with $\mathrm{Fe}_{3} \mathrm{Mo}_{3} \mathrm{C}$ and $\mathrm{Ni}_{3} \mathrm{Mo}_{3} \mathrm{C}$ can also be rationalized by our calculations: among the three bimetallic carbide surfaces, $\mathrm{Co}_{3} \mathrm{Mo}_{3} \mathrm{C}$ surface has the strongest capability of the catalytic decomposition of lithium sulfides (Fig. 7a) and the adsorption of $\mathrm{Li}_{2} \mathrm{~S}_{8}$ on $\mathrm{Co}_{3} \mathrm{Mo}_{3} \mathrm{C}$ surface has medium strength (Fig. $7 \mathrm{~b}$ and Fig. S19), neither over-binding as $\mathrm{Fe}_{3} \mathrm{Mo}_{3} \mathrm{C}$ nor underbinding as $\mathrm{Ni}_{3} \mathrm{Mo}_{3} \mathrm{C}$. Such a tendency can be further well reflected in the electrochemical performance of the Li-S batteries with the different modified separators. The $\mathrm{M}_{3} \mathrm{Mo}_{3} \mathrm{C} / \mathrm{PP}$ separators enable better performance including cycle stability (Fig. 7c) and rate capability (Fig. 7d) of the $\mathrm{S}$ cathode than $\mathrm{Mo}_{2} \mathrm{C} / \mathrm{PP}$ separator, while the $\mathrm{Co}_{3} \mathrm{Mo}_{3} \mathrm{C} / \mathrm{PP}$ separator realizes the best performance among the $\mathrm{M}_{3} \mathrm{Mo}_{3} \mathrm{C} / \mathrm{PP}$ separators.

\section{CONCLUSIONS}

In summary, we proposed a catalytic modification of commercial separator with bimetallic carbide catalyst for high-rate and stable $\mathrm{Li}-\mathrm{S}$ batteries. Compared with monometallic carbide $\mathrm{Mo}_{2} \mathrm{C}$, the catalytic activity of bimetallic carbide $\mathrm{M}_{3} \mathrm{Mo}_{3} \mathrm{C}$ for the polysulfide redox kinetics is significantly enhanced due to the multiple binding sites toward polysulfide species. First-principles calculations reveal the stronger capability of the catalytic decomposition of sulfides on the $\mathrm{M}_{3} \mathrm{Mo}_{3} \mathrm{C}$ surface compared with $\mathrm{Mo}_{2} \mathrm{C}$ and suggest that moderate adsorption of long-chain polysulfide is quite necessary for the better electrochemical performance of $\mathrm{Co}_{3} \mathrm{Mo}_{3} \mathrm{C}$ compared with $\mathrm{Fe}_{3} \mathrm{Mo}_{3} \mathrm{C}$ and $\mathrm{Ni}_{3} \mathrm{Mo}_{3} \mathrm{C}$. Moreover, the catalytically modified separator exhibits excellent mechanical strength and can be reutilized with comparable electrochemical performance. Apart from that, the modified separator fabrication strategy is simple, but significantly effective for high-performance and high Sloading Li-S batteries.

Received 19 April 2020; accepted 3 June 2020;

published online 18 August 2020

1 Griffith KJ, Wiaderek KM, Cibin G, et al. Niobium tungsten oxides for high-rate lithium-ion energy storage. Nature, 2018, 559: 556563

2 Choi JW, Aurbach D. Promise and reality of post-lithium-ion batteries with high energy densities. Nat Rev Mater, 2016, 1: 16013

3 Liu Y, Zhu Y, Cui Y. Challenges and opportunities towards fastcharging battery materials. Nat Energy, 2019, 4: 540-550

4 Pang Q, Liang X, Kwok CY, et al. Advances in lithium-sulfur batteries based on multifunctional cathodes and electrolytes. Nat Energy, 2016, 1: 16132

5 Manthiram A, Fu Y, Chung SH, et al. Rechargeable lithium-sulfur batteries. Chem Rev, 2014, 114: 11751-11787

6 Li G, Wang S, Zhang Y, et al. Revisiting the role of polysulfides in lithium-sulfur batteries. Adv Mater, 2018, 30: 1705590

7 Betz J, Bieker G, Meister P, et al. Theoretical versus practical energy: A plea for more transparency in the energy calculation of different rechargeable battery systems. Adv Energy Mater, 2019, 9: 1803170

8 Peng HJ, Huang JQ, Cheng XB, et al. Review on high-loading and high-energy lithium-sulfur batteries. Adv Energy Mater, 2017, 7: 1700260

9 Fang R, Zhao S, Sun Z, et al. More reliable lithium-sulfur batteries: Status, solutions and prospects. Adv Mater, 2017, 29: 1606823

10 Lin D, Liu Y, Cui Y. Reviving the lithium metal anode for highenergy batteries. Nat Nanotech, 2017, 12: 194-206

11 Li G, Gao Y, He X, et al. Organosulfide-plasticized solid-electrolyte interphase layer enables stable lithium metal anodes for long-cycle lithium-sulfur batteries. Nat Commun, 2017, 8: 850

12 Dai $\mathrm{H}, \mathrm{Gu}$ X, Dong J, et al. Stabilizing lithium metal anode by octaphenyl polyoxyethylene-lithium complexation. Nat Commun, 2020, 11: 643

13 Xiang Y, Li J, Lei J, et al. Advanced separators for lithium-ion and lithium-sulfur batteries: A review of recent progress. ChemSusChem, 2016, 9: 3023-3039

14 Xu N, Qian T, Liu X, et al. Greatly suppressed shuttle effect for improved lithium sulfur battery performance through short chain intermediates. Nano Lett, 2017, 17: 538-543

15 Zhang L, Ling M, Feng J, et al. The synergetic interaction between $\mathrm{LiNO}_{3}$ and lithium polysulfides for suppressing shuttle effect of lithium-sulfur batteries. Energy Storage Mater, 2018, 11: 24-29

16 Huang JQ, Zhang Q, Wei F. Multi-functional separator/interlayer system for high-stable lithium-sulfur batteries: Progress and prospects. Energy Storage Mater, 2015, 1: 127-145

17 Bai S, Liu X, Zhu K, et al. Metal-organic framework-based separator for lithium-sulfur batteries. Nat Energy, 2016, 1: 16094

18 Jeong YC, Kim JH, Nam S, et al. Rational design of nanostructured functional interlayer/separator for advanced Li-S batteries. Adv Funct Mater, 2018, 18: 1707411

19 Yuan H, Peng HJ, Li BQ, et al. Conductive and catalytic triplephase interfaces enabling uniform nucleation in high-rate lithiumsulfur batteries. Adv Energy Mater, 2019, 9: 1802768 
20 Fan L, Li M, Li X, et al. Interlayer material selection for lithiumsulfur batteries. Joule, 2019, 3: 361-386

21 Kong L, Jin Q, Zhang XT, et al. Towards full demonstration of high areal loading sulfur cathode in lithium-sulfur batteries. J Energy Chem, 2019, 39: 17-22

22 Li BQ, Peng HJ, Chen X, et al. Polysulfide electrocatalysis on framework porphyrin in high-capacity and high-stable lithiumsulfur batteries. CCS Chem, 2019, : 128-137

23 Yao H, Yan K, Li W, et al. Improved lithium-sulfur batteries with a conductive coating on the separator to prevent the accumulation of inactive S-related species at the cathode-separator interface. Energy Environ Sci, 2014, 7: 3381-3390

24 Chung SH, Manthiram A. High-performance Li-S batteries with an ultra-lightweight MWCNT-coated separator. J Phys Chem Lett, 2014, 5: 1978-1983

25 Peng HJ, Wang DW, Huang JQ, et al. Janus separator of polypropylene-supported cellular graphene framework for sulfur cathodes with high utilization in lithium-sulfur batteries. Adv Sci, 2016, 3: 1500268

26 Lei T, Chen W, Lv W, et al. Inhibiting polysulfide shuttling with a graphene composite separator for highly robust lithium-sulfur batteries. Joule, 2018, 2: 2091-2104

27 Pang Y, Wei J, Wang Y, et al. Synergetic protective effect of the ultralight MWCNTs/NCQDs modified separator for highly stable lithium-sulfur batteries. Adv Energy Mater, 2018, 8: 1702288

28 Fu A, Wang C, Pei F, et al. Recent advances in hollow porous carbon materials for lithium-sulfur batteries. Small, 2019, 15: 1804786

29 Guo Z, Zhang B, Li D, et al. A mixed microporous/low-range mesoporous composite with high sulfur loading from hierarchically-structured carbon for lithium sulfur batteries. Electrochim Acta, 2017, 230: 181-188

30 Kang N, Lin Y, Yang L, et al. Cathode porosity is a missing key parameter to optimize lithium-sulfur battery energy density. Nat Commun, 2019, 10: 4597

31 Peng HJ, Zhang ZW, Huang JQ, et al. A cooperative interface for highly efficient lithium-sulfur batteries. Adv Mater, 2016, 28: 9551-9558

32 Seh ZW, Yu JH, Li W, et al. Two-dimensional layered transition metal disulphides for effective encapsulation of high-capacity lithium sulphide cathodes. Nat Commun, 2014, 5: 5017

33 Ghazi ZA, He X, Khattak AM, et al. $\mathrm{MoS}_{2} /$ celgard separator as efficient polysulfide barrier for long-life lithium-sulfur batteries. Adv Mater, 2017, 29: 1606817

34 Zhao P, Zhang Z, He H, et al. Cobalt-tungsten bimetallic carbide nanoparticles as efficient catalytic material for high-performance lithium-sulfur batteries. ChemSusChem, 2019, 12: 4866-4873

35 Cheng Z, Pan H, Chen J, et al. Separator modified by cobaltembedded carbon nanosheets enabling chemisorption and catalytic effects of polysulfides for high-energy-density lithium-sulfur batteries. Adv Energy Mater, 2019, 9: 1901609

36 Tao X, Wang J, Liu C, et al. Balancing surface adsorption and diffusion of lithium-polysulfides on nonconductive oxides for lithium-sulfur battery design. Nat Commun, 2016, 7: 11203

37 Zhang J, Li Z, Chen Y, et al. Nickel-iron layered double hydroxide hollow polyhedrons as a superior sulfur host for lithium-sulfur batteries. Angew Chem Int Ed, 2018, 57: 10944-10948

38 Shao AH, Zhang Z, Xiong DG, et al. Facile synthesis of a "two-inone" sulfur host featuring metallic-cobalt-embedded N-doped carbon nanotubes for efficient lithium-sulfur batteries. ACS Appl
Mater Interfaces, 2020, 12: 5968-5978

39 Huang M, Yang J, Xi B, et al. Enhancing kinetics of Li-S batteries by graphene-like N,S-codoped biochar fabricated in $\mathrm{NaCl}$ nonaqueous ionic liquid. Sci China Mater, 2019, 62: 455-464

40 Wang Y, Zhang R, Chen J, et al. Enhancing catalytic activity of titanium oxide in lithium-sulfur batteries by band engineering. Adv Energy Mater, 2019, 9: 1900953

41 Zhang Z, Shao AH, Xiong DG, et al. Efficient polysulfide redox enabled by lattice-distorted $\mathrm{Ni}_{3} \mathrm{Fe}$ intermetallic electrocatalystmodified separator for lithium-sulfur batteries. ACS Appl Mater Interfaces, 2020, 12: 19572-19580

42 Ye H, Sun J, Zhang S, et al. Stepwise electrocatalysis as a strategy against polysulfide shuttling in Li-S batteries. ACS Nano, 2019, 13: 14208-14216

43 Zhao M, Peng HJ, Zhang ZW, et al. Activating inert metallic compounds for high-rate lithium-sulfur batteries through in situ etching of extrinsic metal. Angew Chem Int Ed, 2019, 58: 37793783

44 Du Z, Chen X, Hu W, et al. Cobalt in nitrogen-doped graphene as single-atom catalyst for high-sulfur content lithium-sulfur batteries. J Am Chem Soc, 2019, 141: 3977-3985

45 Zhao CX, Li BQ, Zhao M, et al. Precise anionic regulation of NiFe hydroxysulfide assisted by electrochemical reactions for efficient electrocatalysis. Energy Environ Sci, 2020, 13: 1711-1716

46 Alonso DM, Wettstein SG, Dumesic JA. Bimetallic catalysts for upgrading of biomass to fuels and chemicals. Chem Soc Rev, 2012, 41: 8075-8098

47 Sankar M, Dimitratos N, Miedziak PJ, et al. Designing bimetallic catalysts for a green and sustainable future. Chem Soc Rev, 2012, 41: 8099-8139

48 Luo M, Zhao Z, Zhang Y, et al. PdMo bimetallene for oxygen reduction catalysis. Nature, 2019, 574: 81-85

49 Zhang Z, Wu DH, Zhou Z, et al. Sulfur/nickel ferrite composite as cathode with high-volumetric-capacity for lithium-sulfur battery. Sci China Mater, 2019, 62: 74-86

50 Puello-Polo E, Brito JL. Effect of the type of precursor and the synthesis method on thiophene hydrodesulfurization activity of activated carbon supported $\mathrm{Fe}-\mathrm{Mo}$, Co-Mo and Ni-Mo carbides. J Mol Catal A-Chem, 2008, 281: 85-92

51 Guo L, Wang J, Teng X, et al. A novel bimetallic nickelmolybdenum carbide nanowire array for efficient hydrogen evolution. ChemSusChem, 2018, 11: 2717-2723

52 Liu Y, Li GD, Yuan L, et al. Carbon-protected bimetallic carbide nanoparticles for a highly efficient alkaline hydrogen evolution reaction. Nanoscale, 2015, 7: 3130-3136

53 Zhang Z, Kong LL, Liu S, et al. A high-efficiency sulfur/carbon composite based on 3D graphene nanosheet@carbon nanotube matrix as cathode for lithium-sulfur battery. Adv Energy Mater, 2017, 7: 1602543

54 Chen T, Zhang Z, Cheng B, et al. Self-templated formation of interlaced carbon nanotubes threaded hollow $\mathrm{Co}_{3} \mathrm{~S}_{4}$ nanoboxes for high-rate and heat-resistant lithium-sulfur batteries. J Am Chem Soc, 2017, 139: 12710-12715

55 Mi Y, Liu W, Li X, et al. High-performance Li-S battery cathode with catalyst-like carbon nanotube-MoP promoting polysulfide redox. Nano Res, 2017, 10: 3698-3705

56 Zeng X, Gao X, Li G, et al. Conductive molybdenum carbide as the polysulfide reservoir for lithium-sulfur batteries. J Mater Chem A, 2018, 6: 17142-17147

57 Liang X, Kwok CY, Lodi-Marzano F, et al. Tuning transition metal 
oxide-sulfur interactions for long life lithium sulfur batteries: The "goldilocks" principle. Adv Energy Mater, 2016, 6: 1501636

58 Yin LC, Liang J, Zhou GM, et al. Understanding the interactions between lithium polysulfides and $\mathrm{N}$-doped graphene using density functional theory calculations. Nano Energy, 2016, 25: 203-210

59 Su D, Cortie M, Wang G. Fabrication of N-doped graphene-carbon nanotube hybrids from Prussian blue for lithium-sulfur batteries. Adv Energy Mater, 2017, 7: 1602014

60 Xu ZL, Lin S, Onofrio N, et al. Exceptional catalytic effects of black phosphorus quantum dots in shuttling-free lithium sulfur batteries. Nat Commun, 2018, 9: 4164

$61 \mathrm{Xi} \mathrm{K}$, Chen $\mathrm{B}, \mathrm{Li} \mathrm{H}$, et al. Soluble polysulphide sorption using carbon nanotube forest for enhancing cycle performance in a lithium-sulphur battery. Nano Energy, 2015, 12: 538-546

$62 \mathrm{Xi} \mathrm{K}, \mathrm{He} \mathrm{D}$, Harris $\mathrm{C}$, et al. Enhanced sulfur transformation by multifunctional $\mathrm{FeS}_{2} / \mathrm{FeS} / \mathrm{S}$ composites for high-volumetric capacity cathodes in lithium-sulfur batteries. Adv Sci, 2019, 6: 1800815

63 Zhang Z, Basu S, Zhu P, et al. Highly sulfiphilic Ni-Fe bimetallic oxide nanoparticles anchored on carbon nanotubes enable effective immobilization and conversion of polysulfides for stable lithiumsulfur batteries. Carbon, 2019, 142: 32-39

64 Dai H, Xi K, Liu X, et al. Cationic surfactant-based electrolyte additives for uniform lithium deposition via lithiophobic repulsion mechanisms. J Am Chem Soc, 2018, 140: 17515-17521

Acknowledgements This work was supported by the National Natural Science Foundation of China (21863006, 51662029, 61974082 and 61704096), Youth Science Foundation of Jiangxi Province (20192BAB216001), and Key Laboratory of Jiangxi Province for Environment and Energy Catalysis (20181BCD40004).

Author contributions Zhang Z, Yang ZY and Xi K conceived the idea; Zhang $Z$ prepared the materials, conducted the electrochemical experiments; Shao AH and Xiong DG conducted the characterization of materials; Li HL performed the DFT calculations; Wang JN, Liu JW, Lao CY, Lu SY, Jiang Q, Yu J, Li HL and Kumar RV contributed to the correction of the manuscript; Xi K and Yang ZY revised the manuscript written by Zhang Z. All the authors commented on the manuscript.

Conflict of interest The authors declare that they have no conflict of interest.

Supplementary information online version of the paper.

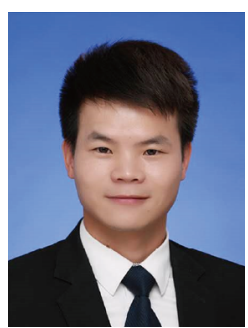

Ze Zhang is a lecturer at the College of Chemistry, Nanchang University. He received his BSc degree in 2012 from the College of Chemistry, and $\mathrm{PhD}$ degree in 2017 from the School of Materials Science and Engineering, Nankai University, China. His main research interest is in the area of advanced functional materials for rechargeable batteries with a focus on the exploration of high-energy Li-S batteries.

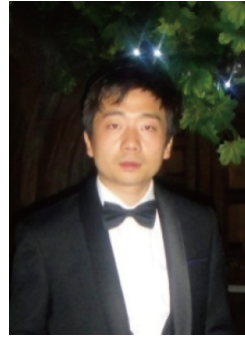

Kai $\mathbf{X i}$ is a research associate at the Cambridge Graphene Centre. He obtained his PhD degree in the Department of Materials Science and Metallurgy, University of Cambridge. His research focuses on materials engineering and physical chemistry for renewable energy conversion and storage, in particular lithium-sulphur (Li-S) batteries, lithium-ion batteries and solar cells. $\mathrm{He}$ was awarded the grand prize of the Dow Sustainability Innovation Student Challenge Award. His CamBattery team was awarded Technology Start Up of the Year by Cambridge University Entrepreneurs in 2012.

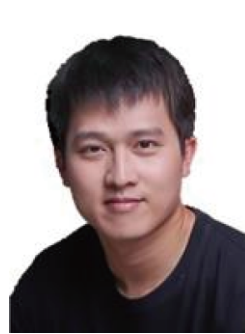

Huang-Long $\mathbf{L i}$ is an associate professor at the Department of Precision Instrument, Tsinghua University. His research interests include nanoelectronics, neuromorphic engineering, $a b$ initio calculations, electronic materials and energy materials. He received his $\mathrm{PhD}$ degree in electrical engineering from the University of Cambridge (2014), and the BSc degree in physics from Peking University (2010).

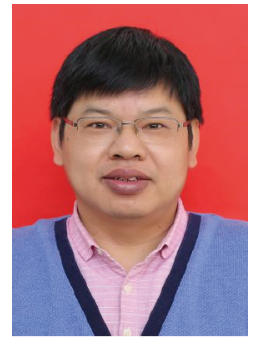

Zhen-Yu Yang is a professor at the School of Chemistry, Nanchang University, China. He received his $\mathrm{PhD}$ degree at the Technical Institute of Physics and Chemistry, Chinese Academy of Sciences in 2005. He used to work as a visiting research fellow at Rensselaer Polytechnic Institute in USA from 2012 to 2013 and at Nanyang Technological University in Singapore in 2019, respectively. Currently, his main research focuses on energy storage materials for power sources, including Li-ion batteries, Li-S batteries, and supercapacitors.

\section{钴-钼双金属碳化物修饰隔膜强化锂硫电池中多 硫化理的吸附和催化转化}

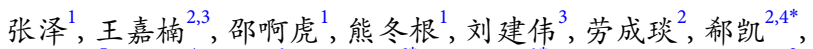
芦世瑶, 江秋 ${ }^{4}$, 呼雯 ${ }^{1}$, 李黄龙 ${ }^{6^{*}}$, 杨震宇 ${ }^{1 *}$, R. Vasant Kumar ${ }^{2}$

摘要 本文报道了一种钻-钼双金属碳化物 $\left(\mathrm{Co}_{3} \mathrm{Mo}_{3} \mathrm{C}\right)$ 催化材料用 于修饰锂硫电池隔膜, 强化多硫化锂的化学吸附和催化转化. 所组 装的电池表现出优异的电化学性能, 即使在 $8.0 \mathrm{mg} \mathrm{cm}^{-2}$ 的硫面积 负载量条件下, 面积比容量仍高达 $6.8 \mathrm{~mA} \mathrm{~h} \mathrm{~cm}^{-2}$. 理论计算结果表 明, 相比于单一金属碳化物 $\mathrm{Mo}_{2} \mathrm{C}$, 双金属碳化物 $\mathrm{Co}_{3} \mathrm{Mo}_{3} \mathrm{C}$ 具有更多 的活性位点, 更利于化学固定多硫化锂, 并催化多硫化锂间相互转 化; 同时, $\mathrm{Ni}_{3} \mathrm{Mo}_{3} \mathrm{C}$ 和 $\mathrm{Fe}_{3} \mathrm{Mo}_{3} \mathrm{C}$ 亦表现出类似的高催化活性. 本研究 对高性能锂硫电池关键催化材料的设计具有一定的指导意义. 